\title{
Attitudes, knowledge and skills of nurses in the Xingu Indigenous Park
}

\author{
Atitudes, conhecimentos e habilidades para o trabalho do enfermeiro no Parque Indígena do Xingu \\ Actitudes, conocimientos y habilidades en el trabajo del enfermero en el Parque Indígena de Xingu
}

'Universidade Federal de São Paulo. São Paulo, São Paulo, Brazil. "Universidade de São Paulo. São Paulo, São Paulo, Brazil.

Juliana Cláudia Leal Martins'
Orcid: 0000-0002-7673-5535
Cleide Lavieri Martins"
Orcid: 0000-0001-7688-0516

Lavínia Santos de Souza Oliveira'

Orcid: 0000-0002-0242-9949

How to cite this article: Martins JCL, Martins CL, Oliveira LSS. Attitudes, knowledge and skills of nurses in the Xingu Indigenous Park. Rev Bras Enferm. 2020;73(6):e20190632. doi: http://dx.doi.org/10.1590/0034-7167-2019-0632

\section{Corresponding author:}

Juliana Cláudia Leal Martins

E-mail: jcleal.mg@gmail.com

EDITOR IN CHIEF: Antonio José de Almeida Filho ASSOCIATE EDITOR: Fátima Helena Espírito Santo

Submission: 11-07-2018

Approval: 01-03-2020

\section{ABSTRACT}

Objective: to analyze the attitudes, knowledge and skills that make up the professional competencies of nurses working in indigenous territories. Method: this is an exploratory-descriptive study with a qualitative approach, conducted with nurses working in the Xingu Indigenous Park in 2016. Data were obtained in semi-structured interviews and treated according to the thematic-categorical analysis method. Results: the nurse's performance in the Xingu Indigenous Park has a multifaceted character, being defined by the territory's interculturality and specificities and by how the service is organized. Technical skills, concepts from anthropology and attitudes that facilitate a respectful dialogue with cultural difference are required for a professional to act in this context. Final considerations: the performance of health professionals in indigenous territories requires specificities associated with the acquisition of new knowledge, attitudes and skills geared to the intercultural dimension of the work developed.

Descriptors: Nursing; Work; Health Services, Indigenous; Professional Competence; Primary Health Care.

\section{RESUMO}

Objetivo: analisar as atitudes, conhecimentos e habilidades que compõem a competência profissional dos enfermeiros para o trabalho nos territórios indígenas. Método: estudo exploratório-descritivo com abordagem qualitativa realizado com enfermeiros atuantes no Parque Indígena do Xingu em 2016. Os dados foram obtidos por meio de entrevistas semiestruturadas e tratados conforme método da análise temático-categorial. Resultados: a atuação do enfermeiro no Parque Indígena do Xingu é definida pela interculturalidade e pelas especificidades do território e da organização do serviço. O trabalho tem caráter multifacetado. Habilidades técnicas, conhecimentos da antropologia e atitudes facilitadoras de uma interlocução respeitosa com a diferença cultural compõem a competência profissional para atuação neste contexto. Considerações finais: o trabalho da saúde nos territórios indígenas abriga especificidades e demanda dos enfermeiros uma prática profissional singular marcada pela aquisição de novos conhecimentos, atitudes e desenvolvimento de habilidades orientadas para a dimensão intercultural do trabalho em saúde.

Descritores: Enfermagem; Trabalho; Saúde de Populações Indígenas; Competência Profissional; Atenção Primária à Saúde.

\section{RESUMEN}

Objetivo: analizar las actitudes, conocimientos y habilidades que conforman la competencia profesional de los enfermeros para trabajar en territorios indígenas. Método: estudio exploratorio descriptivo con enfoque cualitativo, en el cual participaron enfermeros que trabajaban en el Parque Indígena de Xingú en 2016. Los datos se obtuvieron mediante entrevistas semiestructuradas y se sometieron al análisis temático categórico. Resultados: la actuación del enfermero en el Parque Indígena de Xingú se caracteriza por la interculturalidad y las especificidades del territorio y de la organización de servicio. El trabajo tiene un carácter de múltiples facetas. Las habilidades técnicas, los conocimientos en antropología y las actitudes que facilitan una interlocución respetuosa con la diferencia cultural constituyen la competencia profesional para actuar en este contexto. Consideraciones finales: el trabajo con la salud en los territorios indígenas presenta especificidades y exige de los enfermeros una práctica profesional única marcada por la adquisición de nuevos conocimientos, actitudes y desarrollo de habilidades orientadas a la dimensión intercultural del trabajo en salud.

Descriptores: Enfermería; Trabajo; Salud de Poblaciones Indígenas; Competencia Profesional; Atención Primaria de Salud. 


\section{INTRODUCTION}

In Brazil, primary care in indigenous territories is given by Multidisciplinary Indigenous Health Teams (Emsi), which act as an instrument for the implementation of health care based on health surveillance and territoriality. This configuration vastly differs from the previous health care initiatives and models provided to this population, which focused on immediate and emergency care ${ }^{(1)}$.

The current configuration of the health care model came into effect with the implementation of the Indigenous Health Care Subsystem (Sasi) in the late 1990s, a political milestone in the history of the health care of indigenous peoples. Guided by the National Policy on the Health Care of Indigenous Peoples (Pnaspi), published in 2002, Sasi is responsible for ensuring health care in accordance with the doctrinal principles of the Brazilian Unified Health System (SUS), and based on the respect for traditional practices and customs. Moreover, all specificities related to indigenous peoples should be considered when planning and implementing health actions to ensure the good quality of services according to the principle of specialized care $\mathrm{c}^{(1-4)}$.

Sasi-SUS is organized in 34 Special Indigenous Health Districts (Dsei), distributed across the Brazilian territory. Each of these units is responsible for managing a certain territorial space, defined by geographical, population and ethnocultural criteria, and are endowed with political and financial autonomy to ensure the promotion, prevention and control of diseases, based on the local epidemiological profile and cultural specificities ${ }^{(3)}$.

Regarding the work of nursing professionals, their presence and performance in the health care of Brazilian indigenous peoples in the 21 st century is related to the country's political, economic and social history, and to public health policies aimed at this population. Such performance can also be understood as a result of the changes in the profession in Brazil, regarding the offer of training, insertion in the labor market and remuneration ${ }^{(5)}$. From a theoretical point of view, it is inserted in the framework of transcultural nursing, proposed by American nurse Madeleine Leininger in the 1950s, which associates culture with care, seeking conformity between these practices ${ }^{(6)}$.

Mirroring what happens in the health sector as a whole, nursing professionals have been consolidating themselves as the largest category in the composition of the Emsi working in the Dsei ${ }^{(7)}$.

In this context, as members of the Emsi, nurses contribute to the collective and collaborative work developed jointly with other health professionals, including indigenous ones. The proposed health care model suggests that the performance of nursing professionals should be based on a profile that is similar to that of their performance in primary care. However, other important characteristics of the work context contribute to the definition of their professional performance. Geographical dispersion and isolation, insufficient work structure and shortage of medical professionals are factors that add up and contribute to the design of this performance's profile. Autonomy and clinical decision-making are part of the work context.

Considering the work environment within the indigenous territory, the health professional is in direct and constant contact with different conceptions about life and the world, which includes the interpretation of health and of the process of onset of illnesses and cure. The territory is the meeting place between two health care systems with different conceptions and practices: the Western medical system, with knowledge and practices anchored in the paradigm of scientific rationality, and the indigenous health systems, with care and healing practices that represent a type of knowledge that has not been validated and that is inscribed in a distinct cultural universe. This scenario requires professionals to learn to dialogue with different health care practices and conceptions, recognizing their legitimacy ${ }^{(8)}$.

The specificity of this work also imposes the need to train health professionals so they may achieve the professional competencies required to act in harmony with the context.

This need is one of the guidelines of Pnaspi, recognized as fundamental for the adequacy of health practices, including training both at the academic level and of professionals already inserted in the labor market ${ }^{(3)}$. However, historically, academic and professional training actions geared to indigenous health have not prioritized non-indigenous professionals. When present, these actions were characterized by discontinuity, focus on biomedicine and health programs, and disregard of socio-cultural diversity ${ }^{(9)}$. Furthermore, the performance profile of professionals is not defined in Pnaspi, representing a gap in professional training programs.

Knowing the work being developed by nurses in indigenous territories is a way to understand the dimensions of the professional competencies required for acting in intercultural contexts.

Professional competence is a multifaceted concept that can be defined using various theoretical approaches in different fields of expertise. The dialogical perspective considers that competencies are the combination of individual skills and attributes to perform actions in professional practice. It also considers the influence of context, culture and ethical values on the construction of knowledge. In the field of education, this perspective is defended by several theorists, among them Philippe Perrenoud. According to him, competencies can be defined as the ability to effectively mobilize resources in professional situations that require decision-making skill $s^{(10)}$. Professional competencies represent a professional's ability to mobilize resources-cognitive, psychomotor, affective - to solve concrete situations imposed on them daily by the work environment. They are composed of three elements: "skills (knowing how to do), attitudes (knowing how to be) and knowledge (knowing)"(11). In Brazil, professional competencies have become a core concept of policies and programs aimed at training professionals on effective care practices, committed to the principles of SUS and to the modification of the health care reality ${ }^{(12)}$, in the sense of application of practical intelligence at work, a notion that is pertinent to the reality of indigenous health care.

\section{OBJECTIVE}

To characterize the attitudes, knowledge and skills that make up the professional competencies of nurses working in indigenous territory, based on a study conducted in the Xingu Indigenous Park.

\section{METHOD}

\section{Ethical aspects}

The research project was approved by the Research Ethics Committee (Coep) of the Public Health School of the University of São Paulo in 2016. The recommendations of resolution No. $466 / 2012$ of the National Health Council (CNS) were followed. 
The participants' anonymity was ensured by identifying them with letter " $\mathrm{P}$ " for professional, followed by a number, according to the chronological order of the interviews, from first to last.

\section{Type of study}

This is an exploratory-descriptive case study with a qualitative approach.

\section{Study setting}

This study was conducted with nurses working in the Xingu Indigenous Park (PIX). Created in 1961, PIX was the first indigenous land recognized in Brazil, and today corresponds to the geographic territory of Dsei Xingu. Located in the northeastern region of the state of Mato Grosso, with an extension of 2,825,470 hectares, PIX is a multi-ethnic territory that houses indigenous peoples belonging to sixteen ethnic groups ${ }^{(13)}$. According to the Dsei population census, the population in 2018 was of about 6,800 indigenous people. The history of health care in PIX is marked by the presence and performance of Escola Paulista de Medicina (EPM), today the Federal University of São Paulo (Unifesp), which has been developing health care actions in this indigenous land since the 1960s, under a university extension project: the Xingu Project. Health care, teaching and research are the guiding axes of this project, which is still being developed nowadays. This project allowed Unifesp to accumulate experience pertaining to the training of professionals (indigenous and non-indigenous) to act in indigenous health care, adapting the health system to the local specificities ${ }^{(5)}$.

\section{Data source}

A survey conducted prior to the development of the fieldwork indicated the presence of 38 nurses working at Dsei Xingu at the time of the study. The following criteria were adopted to choose the participants: minimum time of one year working in the indigenous territory, and no participation in any systematic process of insertion in and follow-up of the project developed by Unifesp. Based on information provided by Dsei, seventeen professionals who met the research criteria were identified; at the end, the group of participants consisted of eleven nurses with professional experience in the four health regions, and with different work trajectories, which is considered satisfactory in terms of scope and diversity. The number of participants was determined according to the logistics of transportation within the indigenous land and the professionals' work scale. Six professionals who were off duty or could not meet the researcher during the development of the fieldwork did not participate. The number of participants was sufficient to satisfy the saturation criterion, since the information obtained in the interviews became recurrent and complementary, meeting the demands of the study. The information provided by Dsei Xingu and Project Xingu/Unifesp was used as a supplementary source.

\section{Data collection and organization}

All seventeen professionals who met the research criteria were previously contacted, electronically and by telephone. The primary data were collected by the first author in 2016 during a fieldwork trip to the study area. Individual semi-structured interviews addressing professional practice and the learning process were conducted, based on the work developed within the indigenous territory. The questionnaire used was prepared by the researchers and included: the reasons for working in indigenous health care; clashes and conflicts experienced in the work environment; what it takes to develop professional practice, and how experience can contribute to its improvement. No pilot test was performed. The interviews, except for one that took place in the Dsei, were conducted within the indigenous territory, in the work environments of each participant, without the presence of third parties. They lasted two hours on average and were recorded. The transcripts were not returned to the participants for possible corrections. Field notes were also made after each interview.

\section{Data analysis}

The primary data analysis was performed using the content analysis method and the thematic-categorical analysis technique according to Bardin ${ }^{(14)}$, without a data management software.

The initial exploration of the material allowed extracting thematic units from the reports of all participants based on common themes. These units were grouped analogously to develop the primary themes of analysis, which were again grouped and interpreted, resulting in five final categories, three of which are this article's subject of analysis.

The analysis was also supported by concepts from the field of anthropology and education, including the concept of professional competencies.

\section{RESULTS}

The nurses who participated in this study were aged between 26 and 39 years, and there is no relevant predominance between the sexes since five of them were female and six were male. Three of the participants live in the same municipality where the Dsei is located, and only one participant lives outside the state of Mato Grosso. Professional training time ranged between three and seven years. Two had bachelor's degrees from public institutions, and six had bachelor's degrees from the same private institution. Only two had no specialization, while two others were specialized in Indigenous Health Care. For five of them, their first job was working in indigenous health care. The median time working at the Dsei was 27 and a half months. The participants had different work trajectories and experience acting in the indigenous territory of this study.

\section{First category: a meaning for work in indigenous health care}

The reasons that led the participants to work in indigenous health care are diverse. Interest and curiosity, common motivations of all, are often mentioned by the participants. These motivations originated from the previous contact with the indigenous theme during the participants' professional training, from their personal experience, or based on reports of professionals who already had experience in the field. 
I had several friends, colleagues who worked in indigenous health care, and they always spoke highly of it. They did mention difficulties, but generally speaking, they really liked it. (P4)

Job opportunities and remuneration were also motivations, although not explicitly stated by all participants. Expectations of personal and professional fulfillment and even the attractiveness of the natural wonders of PIX were also mentioned.

Along with their motivations and expectations, the participants had conceived an imaginary perception of the workspace, of the indigenous people and of professional practice, composed of few certainties, many fantasies, and permeated by social representations.

\section{[...] / didn'teven consider the money issue. It's more about the personal desire to care for those in need, I don't know... my expectation was to still find people who actually use nature to live. (P8)}

I wanted to do it because I saw that these are people who really, really need it, who were always grateful that you were there helping. (P2)

Geographic isolation, lack of structure and a typical adventure setting were some of the expectations about the work environment and context.

I used to think we were going to be in the middle of a forest, without access to the structure of a basic health unit, that there was none of this here, that we'd be camping [...]. (P3)

[...] Because I came here thinking the conditions were going to be worse. But in truth, I found a much better structure than what I had imagined. (P4)

About the professional performance, the nurses had expected it to be very similar to their previous practices, and that the work process would follow the clinical health care model marked by hierarchy, based on subordination and dependence of medical knowledge. Goodwill and professional charity also permeated the reports.

I'd imagine me, a nurse, a nursing technician and a doctor working as team, and that l'd be there to follow the doctor's instructions, not taking the lead, taking care of all that. (P2)

\section{Second category: clashes, surprises and conflicts in the work context}

Once inserted in the work within the territory, each participant experienced his/her own unique professional and personal trajectory, all united by a common point: the involvement in clashes, surprises and conflicts.

In their narratives, the nurses described an experience that begins with the clash between their preconceived perception and the reality of the work context. The first contact with the indigenous territory was characterized by the participants as an impactful experience, being also their first day at work, thus stored with richness of detail in the memory of each of them.

The beginning of the work experience was defined as a difficult phase, pervaded by conflicts and difficulties. In this meeting between imagination and reality, cultural habits, living conditions, the performance of the indigenous health professionals and even the welcoming behavior of the indigenous peoples stand out as sources of surprise.

The indigenous peoples were portrayed based on a mistaken view of their ways and customs, especially their eating habits, hygiene and housing, which seemed to be quickly apprehended by the professionals from an exploratory and ethnocentric perspective.

What impacted me the most was the issue of food, the way they ate, what they ate, the issue of environmental hygiene itself, and you start thinking: this is all conducive to the onset of illness, technically speaking. (P11)

I think it was really the issue of their family, inside the houses, the issue of food. The first thing they offered me was tracajá (yellowspotted river turtle), and I don't eat tracajá. So, I think that was it, the issue of the animals that I care for, that I took care of and they were eating. (P6)

As members of multidisciplinary teams, the indigenous health professionals stand out for the quality of their technical performance and their active participation in the work process.

It was quite different, because when I got here I was told that there was a nursing assistant, the indigenous health agents were trained, and I didn't know they were already at this... how can I say... this level of education, working as health agents, as nursing assistants. Because here the nursing assistant does things even I didn't use to do, and with the knowledge required for it. This I also found very interesting. It also stood out. (P2)

In fact, I was amazed at the indigenous health agents, especially the ability they have, the experience they've gained here. (P3)

The work of the nurse stood out as a great surprise. Initially characterized by the participants as "different from everything and difficult", the nurse's performance within the indigenous territory surprised all of them, especially for its multifaceted character, due to the position of the professional in the team, performing various activities, often on their own.

I knew that I had to follow a routine, but the duties of the nurse in indigenous health care, I learned those gradually, from my experience with the daily work process. It is still very confusing. You have to do a lot of things, and I mean a lot, at the same time. (P8)

[...] Many issues should be considered. [...] here, there are three fundamental things: good technical ability, of course, teamwork, and knowing how to work with indigenous people. (P10)

The initial surprise slowly starts losing its effect, remaining only as a strong reminder of the impact felt at the beginning. Similarly, conflicts became less frequent. Little by little, and in a very particular way, the professionals begin appropriating the work context and demands, which may suggest a successful adaptation process.

\section{Third category: skills, attitudes and knowledge required for professional performance}

The work of the nurse in PIX was characterized by the participants as different, lonely, and difficult, requiring a variety of skills, 
knowledge and technical and personal attitudes that are indispensable for competent professional practice. Technical proficiency, dynamism, proactivity, autonomy, responsibility, selflessness, teamwork and willingness to learn were terms that stood out in the participants' narratives, composing a set of features that characterize the skills, attitudes and knowledge required in this workspace.

All professionals pointed out technical skill as a requirement, associated with the daily performance of activities that are often not related to the work of the nurse in other environments constantly used by these professionals as a reference for comparison, especially the hospital. Activities and procedures related to maternal and child health care and health emergencies - such as assisting childbirth with complications, suturing, making medical diagnoses and prescribing drug treatments - were frequently mentioned. According to the participants, these activities and procedures are the most demanding in the beginning.

It was possible to infer that, for the participants, carrying out activities not normally performed by nurses, escaping the legal limits of the profession, is understood as autonomy.

The autonomy of nurses is very different from what it's like in the city. As I told you, prescribing medicine is not something we do there. Suture, childbirth, things like that. (P3)

Responsibility was associated with the prominent role of the nurse, who leads the team and takes on a large repertoire of health care and management activities. On the other hand, the participants acknowledged that they are not always technically prepared to perform these activities, which generates discomfort and insecurity, also contributing to the loss of professional identity.

Because I got there and had to act as a nurse, as a dentist, as a doctor, and I wasn't expecting that. [...] That's when I found myself repeatedly in trouble. Damn, I'm playing doctor here, it was something I should not have been doing. (P6)

Because if there's a doctor, you can act more like a nurse, and leave all that clinical demands to him. I think the nurse is always busy doing clinical work, over and over, and forgets to do his job as a nursing professional. (P11)

Teamwork was also mentioned as an essential condition for acting in this context. However, the content of some reports suggests that what was often referred to as teamwork actually meant coexisting in the group.

First, teamwork is everything. If you are not working as a team, you will not be able to optimize the workflow. If you are not working as a team, there is no progress, no evolution. We're almost always here, this is our home. This is our first home, and our second home is there with our families. So, the primary factor is the team, unity, listening to each other. There will be moments when something may happen, but teamwork is everything. (P9)

Despite the relevance given to the technical dimension at the beginning of the experience, over time, other needs start being identified, making the characteristics of the work context clearer.

The ability to interact appropriately with each other (indigenous or not) and with difference was pointed out as the main attitude required. Willingness to listen and dialogue, relativistic posture and respect are among the attributes required to face the demands arising from interculturality, indispensable for developing a dialogic and respectful relationship with the indigenous peoples and their cultures.

Regarding the knowledge associated with the competencies required in this context, the nurses pointed out the insufficiency and frailty of the repertoire offered during professional training, which should provide theoretical support and a better understanding of the work context for the development of skills and attitudes.

Notions and concepts from the field of anthropology, such as culture, cultural relativism, intercultural dialogue and cultural care, were essential to obtain a more comprehensive overview of the sociocultural universe, ensuring a less conflicting relationship with difference. Knowledge of health policies, epidemiology and concepts in the field of primary care were also pointed out as necessary for qualified professional performance, contributing to the overall quality of health care in the territory.

\section{DISCUSSION}

Indigenous health care has been configuring itself as an attractive field for offering a job opportunity with better wages. The salaries paid to nurses working in indigenous health are higher than those offered in the public sector in some regions of the country, including the Midwest. The difficulty of entering the labor market is also a reality, as a result of the disorderly expansion of the offer of undergraduate courses in Brazil in the last two decades, and later in the state of Mato Grosso, from 2006 onwards $^{(15)}$. Thus, the Dsei Xingu acts as a concrete space for the absorption of professionals in the region. One must also consider the influence of the Dsei's selection process, the elimination stages of which are conducted in person, favoring candidates who live in the region.

It was possible to infer that previous contact with the indigenous topic, even if incipient, acts as an invitation to the experience of interculturality and cultural health care, stimulating an imaginary perception of the work context in nurses, based on few certainties, many expectations, and strongly influenced by social representations of the profession and of indigenous peoples.

When facing difference, nurses experience a clash between what is real and what is imaginary, which generates not only surprise, but also certain feelings and impressions. This is because everything experienced starts being analyzed, judged and interpreted under their own references, revealing an ethnocentric stance.

This stance can be interpreted as a natural process experienced by the professionals, who are often unprepared, and thus anxious to translate what they are experiencing ${ }^{(16)}$.

The surprise caused by the performance of the indigenous health professionals seems to result from an underestimated view of the capacity of indigenous people. Contrary to what is observed in other indigenous territories, in PIX, the performance of indigenous professionals who are members of the Emsi has always been very expressive. This is due to the training process developed by Unifesp, which included, among other characteristics, the promotion of indigenous protagonism and the concern with training indigenous health professionals to be able to competently manage the health problems in the territory. 
The reality of the work context and of the nurses' performance in PIX surprised the participants for being very distant from their previous experiences. Some of the characteristics of the professional practice were misunderstood and gave rise to mixed, and sometimes contradictory, feelings.

In PIX, nursing professionals are given autonomy with regard to clinical decision-making, guided by action protocols, a situation that despite being supported by law, is still not well disseminated in SUS. This scenario is partly related to the difficulty recruiting medical professionals to work in indigenous territories, not yet overcome in the implementation of Sasi-SUS. The absence of medical professionals contributes to the work overload experienced by nurses, who are in charge of leading the team. In this position, they are required to manage the main health problems affecting indigenous populations, especially those that stand out in these populations' morbidity and mortality profile, e.g., diarrheal diseases and respiratory infections in children. The understanding of autonomy as simply following a repertoire of technical procedures is a mistake ${ }^{(17)}$. The fact this mistaken notion of autonomy is underpinned by the performance of a set of practices without the knowledge and skills necessary to do so, or that are often outside the legal boundaries of the profession, is concerning. The relationship of nursing professionals with the autonomy of clinical decisions needs to be further studied and discussed.

Another misconception observed was the participants' understanding of teamwork. The oversimplified conception reducing teamwork to the simple coexistence between professionals is very distant from a broader perspective, where teamwork is based on integration of knowledge, interaction between professionals, communication and articulation ${ }^{(18)}$.

An important feature that characterizes the work in PIX is the professional's immersion in the work context due to the long stays in the territory (around 28 days) demanded by the work schedule. Immersion intensifies the experience of interculturality and invites them to experience new interpersonal and social relationships and new living standards, being a source of physical and emotional burnout. With immersion, the workspace becomes the living space, making it impossible to determine the spatial and temporal limits of professional performance.

The "attitudes" component of professional competencies acts as a guide, because in interculturality, even the performance of strictly technical procedures takes place in the context of another culture, permeated by very different notions and interpretations of biomedicine. Dialogue, consideration and negotiation are attitudes that also contribute to a better coexistence between the group and the professional team, minimizing conflicts arising from the intensity of the interpersonal relationships established at work. This component corresponds to the relational dimension present in health care work, where bonds and positive relationships between workers and between them and patients are essential for the production of care. This relational dimension includes ethics. In indigenous health care, work ethics translates into respect for indigenous peoples and the conceptions about the health-disease process, a fundamental attitude for the implementation of the principle of specialized care.

Although the mere acquisition of knowledge is not enough to support the development of competencies, it is of great importance as a supporting matrix for the other components, skills and attitudes. Just as technical actions are anchored in theoretical knowledge offered in the academic environment, the development of attitudes also demands sensitization on the part of the professionals, which can be aroused by acquiring theoretical knowledge from the field of anthropology.

\section{Study limitations}

This study was conducted in the Xingu indigenous land, and although the work process is quite similar to the other indigenous territories of the Amazon and the Midwest region, some local specificities limit its reach, especially in indigenous areas that are closer to urban centers. We must also consider the diversity found in the 34 Dsei, which also has implications for the characteristics of this study. Other relevant indigenous health care workplaces, such as the Indigenous Health Care Centers (Casai) and specialized outpatient clinics, have not been included and should be the subject of future studies. Another limitation of this study is the non-participation of indigenous health professionals, restricting the view on the issues addressed only to non-indigenous references. It could be said that this study provides a Western and materialist perspective on indigenous health care that by no means contemplates the indigenous perspective, which is fundamental to obtain a complete understanding of this reality.

\section{Contributions to the field of nursing}

This study contributes to the scientific production in the field of nursing concerning the training and preparation of nurses to work in intercultural contexts, especially indigenous health care contexts, notably in primary care services, but also in those with greater complexity. The description and analysis of the profile and ways of working of nursing professionals inserted in indigenous health care are still incipient and necessary to improve their professional competencies.

\section{FINAL CONSIDERATIONS}

The characterization of the competencies, skills and attitudes that shape the professional practice of nurses in indigenous territories is based on the combination of knowledge, new practices and new work scenarios that meet the demands arising from the intercultural reality, leading to proactive professional performance, with impacts on the health conditions of the territory and pursuant to the principles and guidelines of Pnaspi.

The nurses' professional practice is also impacted by the particularities of the indigenous territory, and by how the service is organized. Thus, geographical characteristics, logistical issues, the local epidemiological profile, the team's composition, the indigenous health professionals' performance, ethnic plurality and, especially, immersion in the workspace complement the definition of the performance profile of nurses inserted in a specific professional context, unique to each Special Indigenous Health District.

In PIX, nurses occupy a central role in the work of the Emsi, which intensifies the technical dimension, the "know-how" of their professional performance, requiring skills that generally go beyond the 
domain of the profession. When assuming this position, the professionals experience certain feelings, such as autonomy, responsibility, and insecurity. Clinical action and new translations about the body, as well as work that makes use of light technologies, including dialogue, respect, unity, and accountability, are essential to generate positive, productive relational processes alongside indigenous people and within the team, and necessary to exercise intercultural health care.
Thus, the dimension of the attitudes making up professional competencies stands out as necessary to promote the dialogue with difference - with the other -, in a context where interculturality permeates professional performance. The dimension of knowledge supports the other two, skills and attitudes, and is the one that most clearly exposes the gaps to be filled in the training process of professionals.

\section{REFERENCES}

1. Cardoso MD. Políticas de saúde indígena no Brasil: do modelo assistencial à representação política. In: Langdon EJ, Cardoso MD, organizadores. Saúde Indígena: políticas comparadas na América Latina. Florianópolis: UFSC; 2015. p. 83-106.

2. Rodrigues D. Proteção e assistência à saúde dos povos indígenas isolados e de recente contato no Brasil. São Paulo: OTCA; 2014.

3. Ministério da Saúde (BR). Fundação Nacional de Saúde. Política Nacional de Atenção à Saúde dos Povos Indígenas. 2a ed [Internet]. Brasília; 2002 [cited 2015 Jun 12]. Available from: http://bvsms.saude.gov.br/bvs/publicacoes/politica_saude_indigena.pdf

4. Mendonça SBM, Rodrigues D, Pereira PPG. Modelo de atenção à saúde indígena: o caso do DSEI Xingu. Cad Saúde Pública. 2019;35(3):e00008119. doi: 10.1590/0102-311x00008119

5. Machado MH, Oliveira E, Lemos W, Lacerda WF, Aguiar Filho W, Wermelinger M, et al. Mercado de trabalho da enfermagem: aspectos gerais. Enferm Foco. 2016;7(n.esp):35-53. doi: 10.21675/2357-707X.2016.v7.nESP.691

6. Monticelli M, Boehs AE, Guesser JC, Gehrmann T, Martins M, Manfrini GC. Aplicações da Teoria Transcultural na prática de enfermagem a partir de dissertações de mestrado. Texto Contexto Enferm. 2010;19(2):220-8. doi: 10.1590/S0104-07072010000200002

7. Silva CD. De improvisos e cuidados: a saúde indígena e o campo da enfermagem. In: Teixeira CC, Garnelo L, (Orgs.). Saúde indígena em perspectiva: explorando suas matrizes históricas e ideológicas. Rio de Janeiro: Fiocruz; 2014. p. 181-212.

8. Silva CB. Profissionais de saúde em contexto indígena: os desafios para uma atuação intercultural e dialógica. Rev Antropol [Internet]. 2013 [cited 2016 Nov 25];6:3-36. Available from: http://revista.antropos.com.br/downloads/dez2013/Artigo-1-Profissionais-de-saude-emcontexto-indigena-Cleonice-Barbosa-da-Silva.pdf

9. Diehl EE, Pellegrini MA. Saúde e povos indígenas no Brasil: o desafio da formação e educação permanente de trabalhadores para atuação em contextos interculturais. Cad Saúde Pública. 2014;30(4):867-74. doi: 10.1590/0102-311X00030014

10. Lima VV. Competência: distintas abordagens e implicações na formação de profissionais de saúde. Interface. 2005;9(17):369-79. doi: 10.1590/S1414-32832005000200012

11. Saupe R, Benito GAV, Wendhausen ALP, Cutolo LRA. Conceito de competência: validação por profissionais de saúde. Saúde Rev [Internet]. 2006 [cited 2017 Jan 15];8(18):31-7. Available from: http://189.28.128.100/nutricao/docs/Enpacs/pesquisaArtigos/conceito_de_ competencia_validacao_por_prof_saude_2006.pdf

12. Siqueira-Batista R, Gomes AP, Albuquerque VS, Cavalcanti FOL, Cotta RMM. Educação e competências para o SUS: é possível pensar alternativas à(s) lógica(s) do capitalismo tardio?. Cien Saúde Colet. 2013;18(1):159-70. doi: 10.1590/S1413-81232013000100017

13. Instituto Socioambiental. Almanaque socioambiental: Parque Indígena do Xingu: 50 anos. São Paulo: Instituto Socioambiental; 2011.

14. Bardin L. Análise de conteúdo. São Paulo: Edições 70; 2016.

15. Corrêa LZM, Santos NC, Kobi MCB. Expansão dos cursos de graduação em enfermagem em Mato Grosso: implicações e desafios. Rev Eletr Enf. 2014;16(4):744-53. doi: 10.5216/ree.v16i4.22581

16. Pereira PPG. Limites, traduções e afetos: profissionais de saúde em contextos indígenas. Mana. 2012;18(3):511-38. doi: 10.1590/ S0104-93132012000300004

17. Przenyczka RA, Lenardt MH, Mazza VA, Lacerda MR. The paradox of freedom and autonomy in nurses' actions. Texto Contexto Enferm. 2012;21(2):427-31. doi: 10.1590/S0104-07072012000200022

18. Ciampone MHT, Peduzzi M. Trabalho em equipe e trabalho em grupo no Programa de Saúde da Família. Rev Bras Enferm. 2000;53(n. esp):143-7. doi: 10.1590/\$0034-71672000000700024 